\title{
ANALISIS BEBAN KERJA MENTAL DAN FISIK KARYAWAN PADA LANTAI PRODUKSI DENGAN METODE NASA-TLX DAN CARDIOVASCULARLOAD.
}

\author{
Aminah Soleman \\ e-mail: aminahsoleman@gmail.com \\ Jurusan Teknik Industri, Fakultas Teknik, Universitas Pattimura - Ambon
}

\begin{abstract}
ABSTRAK
Pekerjaan yang dilakukan pada bagian devisi proses produksi PT. Fajar Utama Intermedia (FUI) cabang Ambon tergolong pada jenis pekerjaan yang memiliki intensitas kerja yang sangat tinggi karena adanya tekanan dan tegangan dalam menyelesaikan pekerjaan. Hal ini dapat dilihat berdasarkan cara kerja karyawan dituntut bekerja di malam hari dalam posisi berdiri dan harus berkonsentrasi dengan durasi waktu yang lama. Karyawan juga melakukan pergerakan tubuh secara terus menerus untuk mengoperasikan mesin cetak dan merapikan hasil cetakan koran. Responden di ambil dari karyawan yang bekerja pada lantai produksi yang berjumlah 5 orang. Penelitian ini bertujuan untuk mengidentifikasi tingkat beban kerja yang diterima pekerja baik secara mental dan fisik, keluhan yang dialami pekerja serta memberikan usulan waktu istirahat yang efektif. Penelitian diawali dengan penyebaran kuisioner NASA-TLX kepada pekerja dibagian lantai produksi, selanjutnya metode CVL digunakan untuk mengetahui denyut nadi pekerja saat bekerja dan memberikan usulan waktu istirahat dengan menggunakan persamaan Murrel (Pullat, 1992). Berdasarkan hasil penelitian yang telah dilakukan kepada pekerja di bagian lantai produksi didapatkan nilai skor NASA-TLX sebesar 92,52 yang menunjukkan beban kerja yang diterima pekerja termasuk dalam ketegori beban kerja yang sangat tinggi. Berdasarkan hasil dari Pengukuran denyut nadi dengan metode CVL dengan hasil rata-rata untuk pekerja dibagian lantai produksi adalah sebesar 30,51\%, hasil tersebut menunjukkan pekerja harus melakukan perbaikan atas pekerjaannya. Hasil perhitungan dengan menggunakan persamaan Murrel (Pullat, 1992) diusulkan 21 jam waktu istirahat dan 3 jam untuk waktu kerja.
\end{abstract}

Kata Kunci: Cardiovascular Load, NASA-TLX, Persamaan Murrel.

\section{PENDAHULUAN}

Beban kerja dari setiap pekerja berbeda sesuai dengan jenis pekerjaanya. Beban kerja tersebut berpengaruh pada kondisi fisik maupun psikis yang dapat menimbulkan dampak kelelahan bagi pekerja. Menurut Kementrian Kesehatan RI (2014), kelelahan kerja akan menyebabkan terjadinya penurunan produktivitas kerja, sehingga dapat meningkatkan perubahan pada perilaku kerja, jumlah terjadinya kesalahan kerja, ketidakhadiran kerja, berhenti bekerja, dan kecelakaan kerja.

Beberapa penelitian yang telah dilakukan sebelumnya, menunjukan kelelahan kerja memberi kontribusi 50\% terhadap terjadinya kecelakaan kerja (setyawati, 2007). Kelelahan bisa terjadi oleh sebab fisik ataupun tekanan mental. Salah satu penyebab fatique adalah gangguan tidur (sleep distruption) yang antara lain dapat dipengaruhi oleh kekurangan waktu tidur dan gangguan pada circadian rhythms akibat pemberlakuan shift kerja (Wicken, et al, 2004). Sudah dipercaya bahwa sebagian besar dari pekerja yang bekerja pada shift malam memiliki risiko yang lebih tinggi mengalami kecelakaan dibandingkan mereka yang bekerja dalam keadaan normal (shift pagi) (Jostling,1998). Dalam artikelnya yang berjudul Shift Work and III-Health mempertegas anggapan tersebut dengan menyebutkan hasil penelitian yang dilakukan oleh The Circardian Learning Center di Amerika yang menyatakan bahwa para pekerja shift, terutama yang bekerja di malam hari, dapat terkena beberapa permasalahan kesehatan. Permasalahan kesehatan ini antara lain; gangguan tidur, kelelahan, dll. Segala gangguan kesehatan tersebut ditambah dengan tekanan stress yang besar dapat otomatis meningkatkan risiko terjadinya kecelakaan pada pekerja shift malam. Menurut Suma'mur (1993) shift kerja malam perlu mendapat perhatian karena irama faal manusia (circardian ritme) terganggu dan tidak dapat beradaptasi, kelelahan, kurang tidur, alat pencernaan kurang berfungsi secara normal, timbul reaksi psikologis dan pengaruh yang kumulatif. Bagi seorang pekerja, bekerja diatas 8 jam per hari selama seminggu terus menerus jika ditinjau dari segi kesehatan kerja akan menimbulkan masalah terutama bagi pekerja yang tidak dapat menyesuaikan diri dengan lama jam kerja yang dijalaninya (Grandjean, 1991).

PT. Fajar Utama Intermedia (FUI) Cabang Ambon merupakan salah satu perusahaan anak dari Harian Fajar Group. Devisi percetakan ini awalnya, lahir dari sebuah percetakan umum tahun 1980 an dengan nama CV. Centra Bakti Baru. Perusahaan ini mencetak koran harian Fajar Group dan mencetak beberapa buah buku autobiografi, majalah, Koran harian Ambon Express, tabloid, stiker, brosur dll. Soal-soal ujian SD, SLTP, dan SMA. Karyawan PT. FUI Cabang Ambon memproduksi Koran dll, mulai 
pukul 01:00 sampai dengan pukul 04:00 WIT. Artinya waktu tersebut diluar dari jam kerja normal (pagi) karena merupakan waktu lembur. Menurut Grandjean (1991), Sistem kerja dipandang sebagai tuntutan yang menekan setiap individu. Rentang Umur karyawan PT. FUI berkisar 40-50, hal ini menunjukan umur karyawan PT. FUI jauh dari usia produktif, sehingga sangat mempengaruhi kondisi kerja baik secara fisik maupun mental.

Pekerjaan yang dilakukan pada bagian devisi proses produksi PT. Fajar Utama Intermedia (FUI) cabang Ambon tergolong pada jenis pekerjaan yang memiliki intensitas kerja yang sangat tinggi karena adanya tekanan dan tegangan dalam menyelesaikan pekerjaan. Hal ini dapat dilihat berdasarkan cara kerja karyawan dituntut bekerja di malam hari dalam posisi berdiri dan harus berkonsentrasi dengan durasi waktu yang lama. Karyawan juga melakukan pergerakan tubuh secara terus menerus untuk mengoperasikan mesin cetak dan merapikan hasil cetakan koran.

Tekanan fisik maupun mental yang dialami karyawan PT. FUI, adalah dengan adanya aktivitas karyawan pada lantai produksi yang harus bekerja pada kodisi lingkungan yang tidak sesuai. Hal ini juga dapat dilihat dengan adanya pemadaman listrik secara rutin oleh PLN di malam hari sehingga harus menyalakan mesin genset yang menimbulkan kebisingan. Situasi kerja yang seperti ini akan mengakibatkan frustasi karena karyawan karena di tuntut bekerja secara cepat.

Oleh karena itu, perlu untuk mengidentifikasi tingkat beban kerja yang diterima pekerja baik secara mental dan fisik, keluhan yang dialami pekerja serta dapat memberikan usulan waktu istirahat yang efektif sehingga akan meningkatkan produktivitas kerja karyawan PT. FUI cabang Ambon.

\section{KAJIAN TEORI}

Beberapa kajian penelitian yang telah dilakukan yaitu tentang Analisis Beban Kerja Fisik Dan Mental Karyawan Pada Lantai Produksi sudah banyak dilakukan. Salah satunya hasil penelitian dari Diniaty Dewi dan Mulyadi Zukry (2016), yaitu Mengklasifikasikan persentase beban kerja fisik dan mental karyawan yang bekerja pada lantai produksi. Sementara hasil penelitian dari Cahyo Amdry, (2009) tentang Analisis Beban Kerja Pada Aktivitas MMH. Adapun metode yang digunakan yaitu Metode Cardiovasculerload, sehingga dapat Mengetahui berapa lama seorang tenaga kerja dapat melakukan aktivitas pekerjaannya berdasarkan kemampuan dan kapasitas kerjanya. Hasil yang berikutnya yaitu Dapat menilai cardiovasculer strain (Kapasitas Jantung) dari aktivitas yang dilakukan oleh pekerja. Yang membedakan penelitian ini dengan penelitian-penelitian yang telah dilakukan adalah Objek penelitian dilakukan pada karyawan lantai produksi percetakan pada PT. Fajar Utama intermedia. Metode yang digunakan adalah Metode Cardiovaskulerload, metode NASA-TLX dan Pulse Meter, sehingga diharapkan hasil yang akan didapatkan yaitu pengklasifikasian beban kerja fisik dan metal, serta dapat memberikan usulan penentuan waktu istirahat yang baik terkait beban kerja yang dirasakan karyawan di lantai produksi.

\section{METODE PENELITIAN}

Sampel yang digunakan dalam penelitian ini adalah semua menetapkan karyawan yang bekerja di lantai produksi yang berjumlah 5 orang.

Teknik pengambilan data dilakukan dengan mengambil data pengukuran denyut nadi dan penyebaran kuesioner beban kerja mental, pengukuran tersebut dilakukan kepada karyawan yang bekerja di lantai produksi pada saat malam hari, pengukuran denyut nadi dilakukan menggunakan alat pulse oxymeter dan stopwatch untuk memenuhi tahapan metode yang digunakan yaitu metode 10 denyut, setelah itu kuesioner beban kerja mental di sebarkan ke seluruh responden yang telah menjadi populasi dan sampel penelitian ini

Analisis data dilakukan terhadap hasil dari metode 10 denyut atau pengukuran denyut nadi, dan mengetahui seberapa besar tingkat beban kerja fisik yang di rasakan karyawan yang bekerja di lantai produksi, kemudian hasil kuesioner beban kerja mental menjadi tahapan metode Nasa-TLX. Dari hasil tahapan tersebut, diketahui bahwa seberapa besar beban kerja mental yang dirasakan oleh karyawan yang bekerja di lantai produksi. Dari hasil klasifikasi kedua metode tersebut maka dapat di ambil solusi maupun usulan kerja terkait dengan beban kerja fisik dan beban kerja mental yang dirasakan. Berikut adalah Flow chart penelitian yang dapat dilihat pada gambar 1 berikut ini: 


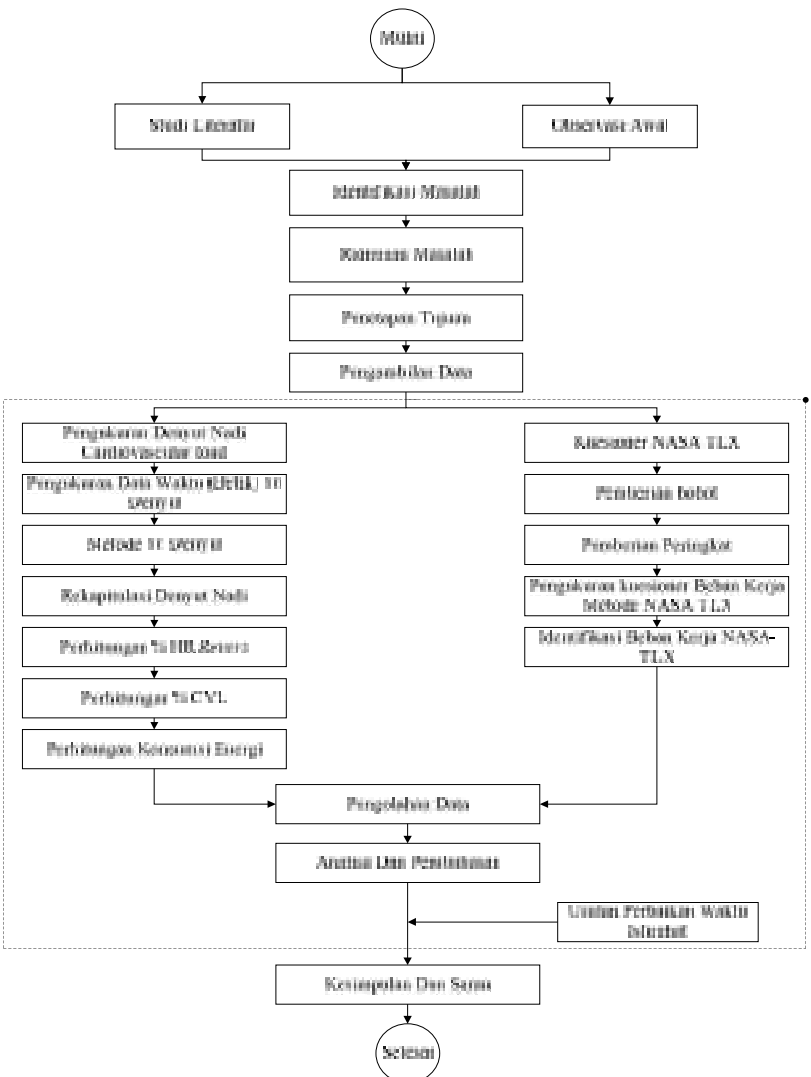

Gambar 1. Flow chart Penelitian

\section{PEMBAHASAN}

\section{Beban Kerja Fisik}

Data pengukuran denyut nadi diukur selama pekerjaan dimulai sampai dengan pekerjaan selesai dilakukan sebanyak 4 kali, dalam selang waktu masing-masing 1 jam, data denyut nadi dengan metode 10 denyut di ukur dari berapa lama waktu denyut nadi 10 denyut itu berlangsung, data denyut nadi dapat di lihat pada tabel 1 , berikut ini:

\section{Tabel 1. Data Waktu Denyut Nadi}

\begin{tabular}{|c|c|c|c|c|c|}
\hline \multirow{2}{*}{ Yiaus } & \multirow{2}{*}{ DDE (ditat) } & \multicolumn{4}{|c|}{ DNK idelik) } \\
\hline & & 1 & 2 & 3 & 4 \\
\hline Muhamadin & 8,58 & 7,3 & 6,12 & 5,3 & 5,5 \\
\hline M walihu & 8,64 & 7,53 & 6,64 & 5,12 & 5,29 \\
\hline Frisno Sistru & 8,72 & 7,42 & 6.52 & 5,05 & 3,22 \\
\hline Ismct Buchar & 9,05 & 7,5 & 5,8 & 5,11 & 5,21 \\
\hline Ahened Bifci & 8.6 & 7,54 & 6.87 & 5,16 & 5,02 \\
\hline
\end{tabular}

\section{Penilaian Beban Kerja Dengan Metode 10 Denyut}

Berikut langkah-langkah perhitungan penilaian beban kerja dengan metode 10 denyut, yaitu sebagai berikut:

\section{1). Penilaian Denyut Nadi Kerja}

Metode penilaian ini adalah dengan menghitung denyut nadi selama bekerja. Pengukuran denyut jantung salama bekerja merupakan suatu metode untuk menilai cardiovasculair strain dengan metode 10 denyut (Kilbon, 1992), Berikut ini persamaan yang digunakan untuk mengihutung denyut nadi kerja

$$
\text { Deuyut Nadi [ Desyyu/Metit })=\frac{10 \text { Denyut }}{\text { Waktu Peritiangan }} \times 60
$$

Tabel 3. Hasil Data Waktu 10 Denyut

\begin{tabular}{|c|c|c|c|c|c|c|c|}
\hline \multirow{2}{*}{ Ners } & \multirow{2}{*}{ I w (*tai) } & \multirow{2}{*}{ xylitaticy } & \multicolumn{4}{|c|}{ Dor $(0): 3]$} & \multirow{2}{*}{$\operatorname{sen} \boldsymbol{x}(\boldsymbol{d} \boldsymbol{k}=k$} \\
\hline & & & ? & ? & 4 & 4 & \\
\hline kicume:je & 4: & $8 \leq 1$ & 23 & 61: & 93 & 8,6 & ills: \\
\hline ki crlint: & 4. & $8 \leqq 4$ & $9 \xi$ & is ist & 511 & $5: 5$ & i15 \\
\hline tisrosidn & 5 & $8 \pi$ & 74 & $6 K 2$ & fits & $5 ! 2$ & i.1t \\
\hline IFme firsier & 5 & 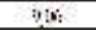 & 75 & $i: A$ & 517 & $5: 1$ & i.1? \\
\hline itreedich & 4il & $8 s$ & 764 & 687 & 516 & 512 & i15 \\
\hline
\end{tabular}

2). Perhitungan Denyut Nadi di Metode 10 denyut

Berdasarkan hasil perhitungan menggunakan persamaan, didapatkan hasil yang dapat dilihat pada tabel berikut:

Tabel 4. Perhitungan Denyut Nadi Metode 10 Denyut

\begin{tabular}{|c|c|c|c|c|c|c|c|}
\hline \multirow{2}{*}{ בעב } & \multirow{2}{*}{ 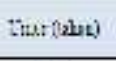 } & \multirow{2}{*}{ 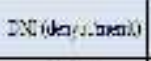 } & \multicolumn{4}{|c|}{ Dik id: retemils? } & \multirow{2}{*}{ Fenditestal uevil! } \\
\hline & & & 1 & : & 1 & & \\
\hline Sithrestit & मा. & (a) $: 54$ & A: $1:$ & $y=1:$ & 132 & $10: 14$ & $71: 32$ \\
\hline Xraling & $1:$ & 69.11 & 7,17 & $y, 35$ & 127.13 & LI: $:$ & $20 . .21$ \\
\hline Tr:an Xith & 56 & $6 \varepsilon .8$ & 8.:56 & $\$ 3,37$ & 1228: & LI: $91^{\circ}$ & $10: \leqslant 5$ \\
\hline sn:trotented & 4: & 462 & $x$ & $x+1$ & 110 & $12 \times 15^{\prime}$ & W: \\
\hline Atrodk fri & A: & $a^{5} \overline{9}:$ & 755 & 8940 & $176, \pi$ & $170 \div$ & 724 \\
\hline
\end{tabular}

3). Rekaptulasi Denyut Nadi.

Untuk data rekapitulasi denyut nadi dapat dilihat pada tabel 5 .

Tabel 5. Rekapitulasi Denyut Nadi.

\begin{tabular}{|c|c|c|c|c|c|}
\hline \multirow{2}{*}{ 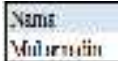 } & \multirow{2}{*}{ 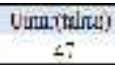 } & \multicolumn{2}{|c|}{ 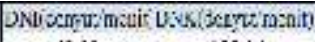 } & \multirow{2}{*}{$\begin{array}{c}\text { JN Nillos } \\
173\end{array}$} & \multirow{2}{*}{$\begin{array}{c}\text { Dodi Kcrja } \\
302\end{array}$} \\
\hline & & sin 93 & 10014 & & \\
\hline Mudisulu & 2 & 69,11 & $36 \mathrm{C.LI}$ & 278 & $30.6 ?$ \\
\hline T-iain si rhu: & 4 & 688 & teryif & 164 & 31.35 \\
\hline -ane: 7imtun & 50 & ifi:2 & $3 C e_{2} n$ & 170 & $73: 98$ \\
\hline Atemsd R:fi. & 20 & 69,75 & 260.12 & 280 & 2066 \\
\hline \multicolumn{2}{|c|}{ Kurats } & $6 \times 8$ & $300,31)$ & 173 & 3: 474 \\
\hline
\end{tabular}

Keterangan :

DN Maks : Denyut Nadi Maksimal, 220 - umur untuk pria; dan 200 - umur untuk wanita Nadi Kerja : didapat dari (DNK - DNI)

Berdasarkan tabel 5. dapat dilakukan perhitungan berikut ini:

(1) Perhitungan \% HR Revers

$$
\begin{aligned}
\% \text { HR Revers } & =\frac{D-D}{D{ }^{M}-5,-D} \\
& =\frac{1^{-D}{ }^{-6}, 3}{1} \times 100 \\
& =30,51
\end{aligned}
$$

(2) Perhitungan cardiovascular strain (\%CVL)

$$
\begin{aligned}
\text { \%CVL } & =\frac{1 x(D-D)}{D M-D}-{ }^{-D}-6,3 \\
& =\frac{1 \times(1-6,3}{1-6,} \\
& =30,51
\end{aligned}
$$

(3) Perhitungan Konsumsi energi (Energy Expenditure)

$$
\begin{aligned}
\mathrm{E}= & 1,80411-0,0229038 \mathrm{X}+4,71733 \times 10^{-4} \mathrm{X} 2 \\
= & 1,80411-0,0229038(100,30)+4,71733 \times \\
& 10^{-4}(100,30)^{2} \\
= & 4,252535296
\end{aligned}
$$




\section{Beban Kerja Mental}

Data pengukuran beban kerja menggunakan metode NASA-TLX menggunakan kuesioner beban kerja, didalamnya tersedia pembobotan, dan pemberian peringkat. Hasil pengukuran dapat dilihat pada tabel 2

Tabel 2. Data Pengukuran Beban Kerja NASATLX

\begin{tabular}{|c|c|c|c|c|c|c|c|c|c|c|c|c|}
\hline \multirow{3}{*}{ Kas } & \multirow{2}{*}{\multicolumn{6}{|c|}{$t=x:$}} & \multirow{2}{*}{\multicolumn{6}{|c|}{ late }} \\
\hline & & & & & & & & & & & & \\
\hline & Sin & 1 & in & $11^{7}$ & 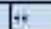 & 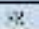 & the? & Q15? & K7: & xat & 6:11 & $x+3$ \\
\hline Xdyein & 4 & 1 & $\bar{I}$ & i & 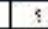 & , & 59 & I & 4 & 5 & $x$ & $\pi$ \\
\hline 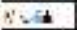 & + & 1 & ; & . & F & 4 & st & 9 & ! & $\pi$ & 7 & $\frac{5}{k}$ \\
\hline Ihise Slla & 4 & I & 1 & 1 & 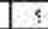 & , & 35 & 8 & 7 & 8 & $x$ & c \\
\hline$a \mathrm{Bin}$ & : & 1 & 1 & 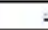 & $!$ & 5 & 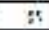 & $n$ & ?! & 5 & 8 & 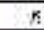 \\
\hline 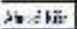 & 7 & 2 & 1 & . & . & 7 & 51 & $t$ & $\%$ & 51 & 3 & $s$ \\
\hline
\end{tabular}

Keterangan : (MD)Mental Demand, (PD) Phisycal Demand, (TD) Temporal Demand, (PF) Performance, (EF) Effort, (FR) Frustation. Tambahan (W) merupakan Workload / beban kerja

\section{Penilaian Beban Kerja Menggunakan Metode NASA-TLX}

Beban Kerja NASA-TLX dapat di hitung dengan rumus sebagai berikut :

$(\mathrm{WMD} \times \mathrm{RMD}+\mathrm{WPD} \times \mathrm{RPD}+\mathrm{WTD} \times \mathrm{RTD}+\mathrm{WOP} \times \mathrm{R}$ $\underline{\mathrm{OP}+\mathrm{WEF} \times \mathrm{REF}+\mathrm{WFR} \times \mathrm{RFR})}$

Berikut ini hasil rekapitulasi berdasarkan perhitungan dengan penggunakan persemaan tersebut

\section{Tabel 6. Rekapitulasi Workload NASA-TLX}

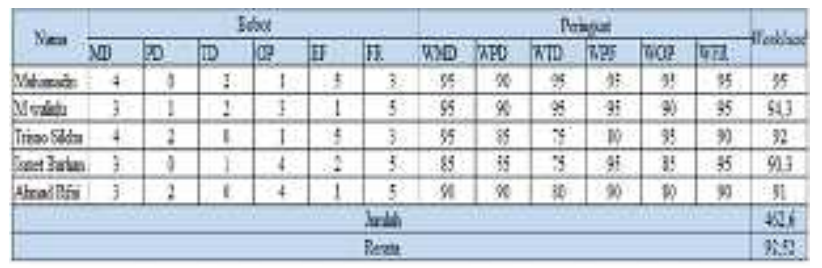

\section{Pengukuran Waktu Istirahat.}

Dari penelitian yang dilakukan nilai konsumsi energi yang dihasilkan adalah 4,252535296 $\mathrm{Kkal} / \mathrm{min}$, hasil ini kemudian dapat di hitung atau dikonversikan kedalam kebutuhan waktu istirahat dengan menggunakan persamaan Murrel (Pullat, 1992) sebagai berikut :

$$
\text { (2) }-\frac{K: S L I(X S) ; B N}{7} \quad \text { unituks }=\mathrm{k}=2 \mathrm{~S}
$$

Karena $\mathrm{K}=4,252535296$ dan $\mathrm{S}=5$ (standar energi yang dikeluarkan pria). Maka perhitungan waktu istirahat yaitu sbb :

$$
\text { ki } X / S 1 \times T(X) / B M
$$

$\mathrm{Rt}=\underline{4,252535296 / 5 \times 240(4,252535296 \times 5) / 1,7}$

$$
\begin{aligned}
& =\frac{2553,043263}{2} \\
& =1276,521631 \text { menit. }
\end{aligned}
$$

Jadi hasil dari perhitungan waktu istirahat adalah 1276,521631 menit dan di konversikan ke dalam jam adalah 21,27536052, atau 21 jam istirahat untuk pekerja yang bekerja di lantai produksi.

\section{ANALISA DATA}

\section{Penilaian Beban Kerja Fisik.}

Berdasarkan hasil pengolahan data, Maka hasil penilaian beban kerja 10 denyut, didapatkan hasil sebagai berikut:

Tabel 7. Hasil Penilaian Beban Kerja 10 denyut

\begin{tabular}{|c|l|c|}
\hline NO. & \multicolumn{1}{|c|}{ Keterangan } & Hasil \\
\hline 1 & $\begin{array}{l}\text { Rerata DNI (Denyut Nadi } \\
\text { Istirahat) }\end{array}$ & 68,83 \\
\hline 2 & Rerata DNK (Denyut Nadi Kerja) & 100,3 \\
\hline 3 & $\begin{array}{l}\text { Rerata DN Maks (Denyut Nadi } \\
\text { Maksimal) }\end{array}$ & 173,0 \\
\hline 4 & Rerata NK (Nadi Kerja) & 31,47 \\
\hline NO. & \multicolumn{1}{|c|}{ Keterangan } & Hasil \\
\hline 5 & HR Revers (\%) & 30,51 \\
\hline 6 & CVL (\%) & 30,51 \\
\hline 7 & Energy Expenditure (Kkal/min) & 04,25 \\
\hline
\end{tabular}

Dari tabel diatas dapat dilihat bahwa \% CVL diklasifikasikan pada beban kerja sedang karena berkisar 100-125 denyut, hasil dari nilai denyut nadi kerja bernilai 100,30 denyut/menit dan \%CVL $30,51 \%$, jika dilihat dari tabel klasifikasi berat atau ringannya beban kerja \%CVL 30,51\% adalah termasuk beban kerja yang harus memerlukan perbaikan agar meminimasi kelelahan kerja. Kemudian untuk konsumsi energi (Energy Expenditure) tergolong dalam beban kerja ringan dengan hasil nilai yaitu 4,252535296.

\section{Penilaian Beban Kerja Mental}

Hasil perhitungan beban kerja mental menggunakan metode NASA TLX, Faktor yang paling dominan mempengaruhi beban kerja mental dapat diketahui dengan cara melihat hasil dari seberapa sering indikator dipilih oleh responden. Faktor dominan dapat dilihat pada gambar 2 .

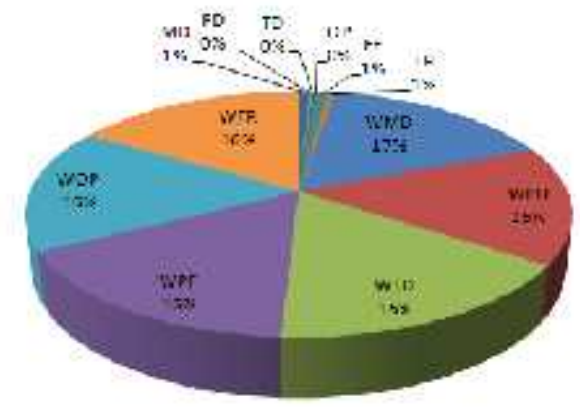

\section{Gambar 2. Chart Beban Kerja Dominan}

Berdasarkan gambar diatas indikator bobot yang memiliki nilai skor yang dominan dipilih 
masing-masing dengan nilai $1 \%$ adalah bobot $\mathrm{MD}$ (Mental Demand) atau kebutuhan mental, bobot EF (Effort) atau tingkat usaha, dan bobot FR (frustation) atau tingkat frustasi, sedangkan 3 indikator lain adalah indikator yang paling jarang dipilih yaitu PD (Physical Demand) atau kebutuhan fisik, TD (Temporal Demand) atau kebutuhan waktu, dan OP (Own Performance) atau perfomansi. Kemudian untuk beban kerja (Workload) indikator yang paling dominan dipilih adalah WMD (Workload Mental Demand) dengan nilai 17\% dan 5 indikator lain masing-masing setara yaitu dengan nilai $16 \%$.

Berdasarkan hasil perhitungan beban kerja mental menggunakan metode NASA TLX, didapatkan hasil skor NASA TLX seperti m pada tabel 8 berikut ini.

Tabel 8. Hasil Skor NASA-TLX.

\begin{tabular}{|l|l|}
\hline Nama & Workload \\
\hline Muhamadin & 95 \\
\hline M waliulu & 94,3 \\
\hline Trisno Silehu & 92 \\
\hline Ismet Burhan & 90,3 \\
\hline Ahmad Rifai & 91 \\
\hline Jumlah & 462,6 \\
\hline
\end{tabular}

Tabel 8 menunjukan bahwa masing-masing pekerja memiliki beban kerja yang tinggi yaitu dengan nilai rerata beban kerja yang dimiliki yaitu 92,52, berdasarkan klasifikasi beban kerja NASATLX, nilai 80-100 adalah beban kerja yang sangat berat, jadi rerata yang didapat dari perhitungan NASA-TLX dengan nilai 92,52 adalah beban kerja mental yang sangat berat di lakukan oleh pekerja dilantai produksi.

\section{Hasil Penentuan Waktu Istirahat}

Dari hasil penelitian yang dilakukan nilai penentuan waktu istirahat adalah 1276 menit dan dikonversikan ke dalam satuan jam yaitu 21 jam, waktu kerja yang ditentukan oleh perusahaan untuk pekerja dilantai produksi adalah 4 jam, dalam hal ini dapat dikatakan bahwa pekerja harus istirahat dalam waktu 21 jam sebelum bekerja dan sisa waktu dipakai untuk bekerja pada malam hari yaitu 3 jam. Hasil perhitungan penentuan waktu istirahat dapat dilihat pada tabel 8 .

Tabel 10. Hasil Penentuan Waktu Istirahat

\begin{tabular}{|c|c|}
\hline Keterangan & Hasil \\
\hline Rt (Waktu istirahat) & 1276,521631 menit \\
\hline $\begin{array}{c}\text { Konversi ke Jam }= \\
1276,521631 \text { menit/60 } \\
\text { menit }\end{array}$ & 21,27536052 Jam \\
\hline
\end{tabular}

\section{Usulan Waktu Istirahat.}

Data yang didapat dari penelitian yang dilakukan, adalah beberapa pekerja memiliki waktu kerja malam di lantai produksi dan diwaktu siang adalah pekerjaan tambahan, hal ini dapat menyebabkan gangguan mental maupun fisik, karena dari pekerjaan malam yang mereka lakukan, fungsi fisiologi benilai rendah, sebagai contoh suhu inti dan detak jantung mengawali irama diurnal tubuh. Yang didukung oleh ketidak aktifan pada malam hari. Selama siang aktivitas puncak biasanya bertepatan dengan nilai tinggi dari fungsi internal. Biasanya pengamatan irama diurnal diperoleh berdasarkan hasil internal (endogenous) dan eksternal (exogenous) yang terjadi. Jika terjadi ketidak seimbangan antara keduanya tersebut dapat muncul permasalahan kesehatan.

Jadi dari hasil perhitungan waktu istirahat yaitu dengan nilai 1276 menit atau 21 jam dapat diusulkan kepada para pekerja sebagai waktu istirahat yang efektif sebelum memulai pekerjaan saat malam hari, agar kemampuan kerja dan kesegaran jasmani tetap dapat dipertahankan dalam batas-batas toleransi. Pemberian waktu istirahat tersebut secara umum dimaksudkan untuk:

a. Mencegah terjadinya kelelahan yang berakibat kepada penurunan kemampuan fisik dan mental serta kehilangan efisiensi kerja.

b. Memberi kesempatan tubuh untuk melakukan pemulihan atau

c. penyegaran.

d. Memberikan kesempatan waktu untuk melakukan kontak sosial.

\section{KESIMPULAN}

Berdasarkan hasil penelitian dapat diambil kesimpulan sebagai berikut:

1. Hasil Beban kerja fisik dengan metode cardiovascularload adalah rerata DNI (denyut Nadi Istirahat) dengan nilai 68,83 , rerata DNK (denyut Nadi Kerja) dengan nilai 100,3, rerata Denyut Nadi maksimal dengan nilai 173 , rerata Nadi Kerja dengan nilai 31,47, persentase Heart Revers dan persentase cardiovascular dengan nilai $30,51 \%$, dan Energy Expenditure dengan nilai 4,252535296 Kkal/menit. Dari hasil \%CVL menunjukkan bahwa nilai $30,51 \%$ adalah beban kerja sedang bagi para pekerja, jika dilihat dari klasifikasi \%CVL maka harus dilakukan perbaikan. Kemudian dari hasil penelitian untuk beban kerja mental, masing-masing pekerja adalah muhamadin dengan nilai beban kerja 95, M waiulu dengan nilai beban kerja 94,3, Trisno Silehu dengan nilai beban kerja 92, Ismet Burhan dengan nilai beban kerja 90,3, dan Ahmad rifai dengan nilai beban kerja 91. Dari semua nilai beban kerja masing-masing pekerja dapat dilihat 
bahwa beban kerja memiliki rerata yaitu 95,52\%, jika dilihat dari klasifikasi beban kerja NASATLX nilai tersebut menandakan bahwa pekerja memiliki beban kerja yang sangat tinggi.

2. Berdasar hasil perhitungan untuk penentuan waktu istirahat melalui perhitungan konsumsi energi yang dibutuhkan selama bekerja yang dikonversikan kedalam kebutuhan waktu istirahat menyatakan bahwa hasil perhitungan waktu istirahat yaitu dengan nilai 1276 menit atau 21 jam dapat diusulkan kepada para pekerja sebagai waktu istirahat yang efektif sebelum memulai pekerjaan saat malam hari, agar kemampuan kerja dan kesegaran jasmani tetap dapat dipertahankan dalam batas-batas toleransi. Pemberian waktu istirahat tersebut secara umum dimaksudkan untuk:

a) Mencegah terjadinya kelelahan yang berakibat kepada penurunan kemampuan fisik dan mental serta kehilangan efisiensi kerja.

b) Memberi kesempatan tubuh untuk melakukan pemulihan atau penyegaran.

c) Memberikan kesempatan waktu untuk melakukan kontak sosial.

\section{DAFTAR PUSTAKA}

Atik Muftia, 2005. Hubungan antara Faktor Fisik dengan Kelelahan Kerja di PT.

Sinar Sastro Ungarang Semarang, Skripsi. Semarang: UNDIP.

As'ad, M. (1987). Hubungan Faktor Umur, Pendidikan, Masa Kerja dan Kepuasan Kerja terhadap Produktifitas Kerja pada Petugas Dinas Luar Asuransi. Penelitian Fakultas Psikologi UGM, Yogyakarta.

Antara, News (2010). Angka Kecelakaan Kerja Tahun Turun. http://apindo.or.id/index.php /berita-artikel/kliping/371-angka- kecelakaankerja-\%20ahun-2010-turun (diakses tanggal 24 Juli 2018)

Attwood Dennis A, Joseph M, Danz-Reece Mary E. (2004). Ergonomic Solution For The
Process Industries. Elsevier Inc. Barlington USA.

Depdikbud. (1996). Ketahuilah Tingkat Kesegaran Jasmani Anda. Pusat Kesegaran Jasmani dan Rekreasi Departemen Pendidikan dan Kebudayaan. Jakarta.

Guyton (1990), Fisiologi Manusia dan Mekanisme Penyakit Edisi III. EGC. Jakarta.

Grandjean, E. 1993. "Fitting the task to the man, 4 th ad. Taylor \& Francis Inc".London.

Henni, Nurina, Syifa Fauziah Abbas. (2011), Analisis Pengaruh Shift Kerja Terhadap Beban Kerja Dengan Menggunakan Metode SWAT. Universitas Persada Indonesia, Teknik Industri.

Kuswadji, S. (1997). Pengaturan Tidur Pekerja Shif., Cermin Dunia Kedokteran No. 116/1997, 48 - 52. Jakarta.

Manuaba, A. (2000). Ergonomi, Kesehatan dan Keselamatan kerja, Proceeding Seminar Nasional Ergonomi. Editor : Wignyosoebroto,S \& Wiranto, S.E Guna Widya, Surabaya.

Marras, W. dan Karwowski, W. (2006). Fundamentals and Assesment Tools For Occupational Ergonomicsm. Third Edition, Taylor and Francis. Boca Raton.

Rachma Sekar Pamungkas. (2017). “Analisis Beban Kerja di Bagian Pengepakan

(Studi Kasus : PT Perkebunan Nusantara IX Kebun Batujamus Pabrik RSS Kerjoarum Karanganyar)." Skripsi, Universitas Muhammadiyah Surakarta.

Widodo, S. (2008). "Penentuan Lama Waktu Istirahat Berdasarkan Beban Kerja dengan Menggunakan Pendekatan Fisiologis (Studi Kasus pada Pabrik Minyak Kayu Putih Krai, Jawa Tengah)". Skripsi, Universitas Muhammadiyah Surakarta.

Zulfikar Hatapayo. (2017). "Analisis Beban Kerja shift pada Perawat Ruang Unit Gawat Darurat (UGD) dengan metode 10 denyut (studi kasus : rumah sakit umur daerah masohi)" Skripsi Universitas Pattimura Ambon.” 